\title{
Digestibility and pricing of Chlorella sorokiniana meal for use in tilapia
}

\section{feeds}

\author{
Rafael Simões Coelho Barone ${ }^{1}$, Daniel Yokoyama Sonoda² Evandro Kleber Lorenz $^{1}$, José Eurico Possebon Cyrino ${ }^{1 *}$
}

'University of São Paulo/ESALQ - Dept. of Animal Science, Av. Pádua Dias, 11 - 13418-900 - Piracicaba, SP - Brazil. 21-PECEGE, R. Alexandre Herculano, 120 - 13418-445 Piracicaba, SP - Brazil.

*Corresponding author <jepcyrino@usp.br>

Edited by: Paulo Cesar Sentelhas

Received November 16, 2016

Accepted March 14, 2017

\begin{abstract}
Several microalgae contain in excess of $50 \%$ crude protein with amino acid profile comparable to that of fish meal. In addition, high polyunsaturated fatty acid contents encourage their use in animal feeding and nutrition, particularly in the formulation and processing of aquafeeds. This study aims at estimating the feasibility of Chlorella meal as feed ingredient for the feeding and nutrition of farmed tilapia based upon digestibility data. Juvenile tilapia were stocked in conical-bottomed tanks (200 L) with superficial, continuous water flow, and fed to apparent satiation in three daily meals with a reference diet and a test diet containing $30 \%$ lyophilized Chlorella sorokiniana added of an inert marker. Feces were collected overnight by sedimentation in refrigerated, plastic containers coupled to the tanks and analyzed for determination of chemical composition and inert marker contents to estimate apparent digestibility coefficients (ADCs) of protein and energy of Chlorella meal; registered ADCs of Chlorella meal were 90.5 and 84.22 , respectively. A pricing model considering the quantity of digestible nutrient was proposed based on ADCs of Chlorella and compared with the price of fishmeal (FM) and soybean meal (SBM). The indicative prices to elicit the use of Chlorella as a protein source rather than FM or SBM for the feed and nutrition of tilapia were $2.65 \mathrm{USD} \mathrm{kg}^{-1}$ and $0.66 \mathrm{USD} \mathrm{kg}^{-1}$, respectively. Keywords: fish nutrition, microalgae, fishmeal, pricing model
\end{abstract}

\section{Introduction}

While the production of oils by plants such as palm, coconut and physic nut (Jatropha curcass) average $5,960,2,689$ and $1,982 \mathrm{~L} \mathrm{ha}^{-1} \mathrm{yr}^{-1}$, respectively, productivity estimates from laboratory data for some species of microalgae range on 10,000 and $60,000 \mathrm{~L} \mathrm{ha}^{-1} \mathrm{yr}^{-1}$ (Chisti, 2007; Chisti, 2008; Ranjitha and Vijayalakshmi, 2015; Singh and Singh, 2014). The farming of microalgae as potential raw material for the production of biodiesel has thus expanded rather quickly in recent decades. However, production of biodiesel from microalgae was never shown economically competitive because of high costs associated with agglutination, centrifugation, drying and lysis of cells for extraction of lipids (Demirbas and Demirbas, 2011; Nascimento et al., 2014). In this scenario, research on the use of microalgae by the pharmaceutical and cosmetics industries, human and animal nutrition has gained grounds in recent years.

Several microalgae contain in excess of $50 \%$ crude protein $(\mathrm{CP})$ with amino acid profiles comparable to that of fishmeal, the standard feedstuff for aquafeeds, and are a rather rich source of polyunsaturated fatty acids (PUFA), especially of the $\mathrm{n}-3$ series. The use of microalgae in fish nutrition has thus been considered as a tool to enhance filet quality via deposition of n-3 PUFA, and replacement of fish meal and fish oil in aquafeeds (Christaki et al., 2011; Becker, 2007; Sarker et al., 2016a; Sarker et al., 2016b; Tulli et al., 2012; Tibaldi et al., 2015; Roy and Pal, 2015).

Reports on the use of Chlorella sp. in fish nutrition have shown both its potential as immunostimulant (Zah- ran and Risha, 2014; Grammes et al., 2013), pigment (Sergejevova and Masojidek, 2012; Gouveia et al., 2003), provitamin A source (Gouveia et al., 1998; Gouveia et al., 2002), performance enhancer (Xu et al., 2014), protein feedstuff (Mahboob et al., 2012) and surrogate protein source to fish meal (FM) in diets for Macrobrachium rosenbergii (Radhakrishnan et al., 2014). However, no information was found on the costs of Chlorella meal targeting economic viability of its use in fish feeding and nutrition.

Although price of soybean meal (SBM) is lower than that of FM, the use SBM in fish diets could induce alterations in the intestine epithelium, already referred to as SBM-induced enteropathy (SBMIE) (Grammes et al., 2013; Krogdahl et al., 2015; Krogdahl et al., 2010). The search for novel protein sources with competitive prices thus has become an important research line.

The pricing of new ingredients should consider not only their biological value, but also the price of ingredients ordinarily used in feed formulation for animal nutrition (Chauton et al., 2015; Maisashvili et al., 2015). The aim of this study was to define the price range to make Chlorella meal viable as a feed ingredient in diets for tilapia based on digestibility data.

\section{Materials and Methods}

\section{Tilapia as a biological model}

Fish of the genus Oreochromis sp. are universally known as tilapia and belong to the Cichlid family. They are originally from the African continent and have been introduced in several, tropical and subtropical countries 
during the second half of the twentieth century (Eknath and Hulata, 2009). As a group, tilapia are the second most farmed fish in the world, recording $3 \times 10^{6} \mathrm{t}$ in 2009 (Ng and Romano, 2013).

\section{Experimental procedures}

Digestibility trial was carried out in an open, continuous water flow system, under controlled temperature $\left(27 \pm 2^{\circ} \mathrm{C}\right)$, oxygen $\left(5 \pm 0.5 \mathrm{mg} \mathrm{L}^{-1}\right), \mathrm{pH}(7$ \pm 0.5 ) and photoperiod ( $12 \mathrm{~h}$ light $+12 \mathrm{~h}$ dark). Tilapia juveniles (78.01 $\pm 1.87 \mathrm{~g}$ ) were stocked in a $500-\mathrm{L}$ tank $(\mathrm{n}=150)$ and acclimatized for $15 \mathrm{~d}$ feeding to apparent satiation on a commercial feed $(32 \%$ crude protein - CP) in three daily meals. Fish were then split into six groups, stocked in six, 200-L conical tanks (20 fish per tank, $n=3$ ), and feed conditioned for $10 \mathrm{~d}$ to the experimental diets added of an inert marker, fed to apparent satiation three times a day $(08 \mathrm{~h} 00,12 \mathrm{~h} 00$ and 18h00). After the last meal, tanks were cleaned, approximately $90 \%$ of the water exchanged and $200-\mathrm{mL}$ plastic flasks were coupled to the tank bottom, kept cooled within iceboxes, and feces where then collected by sedimentation (NRC, 2011) from 07:00 to 19 h00 the next day. At the end of collection period, flasks where drained, centrifuged $\left(3,100 \mathrm{~g} ; 5{ }^{\circ} \mathrm{C} ; 10 \mathrm{~min}\right)$ and fecal material immediately frozen-stored $\left(-80^{\circ} \mathrm{C}\right)$ until analysis. Frozen feces pellets were lyophilized and analyzed for proximate composition (protein, energy and dry matter), chromium oxide contents and amino acid profile (AOAC, 1999).

\section{Experimental diets}

A nutritionally complete, reference diet meeting all nutritional requirements for tilapia $(\mathrm{Ng}$ and Romano, 2013; Shiau, 2002) was processed by extrusion and experimental diets were obtained by adding Chlorella sorokiniana meal (CSM) to the reference diet at a 3:7 ratio. Both diets were added of $0.2 \%$ chromic oxide $\left(\mathrm{Cr}_{2} \mathrm{O}_{3}\right)$ as inert marker (Table 1). Chorella sp. meal was obtained from whole, lyophilized, non-commercial, animal nutrition grade cells harvested from autotrophic system (Algae Company; Piracicaba, SP, Brazil).

The reference diet was processed from finely ground $(1 \mathrm{~mm})$ ingredients and processed in experimental extruder, $3 \mathrm{~mm}$ die head. Pellets were dried in forced-air oven $\left(45^{\circ} \mathrm{C}\right)$ for $24 \mathrm{~h}$, stored in opaque plastic bags and kept under refrigeration $\left(4^{\circ} \mathrm{C}\right)$ until use.

\section{Estimation of apparent digestibility coefficients}

Apparent digestibility coefficients (ADC) for protein, energy and amino acids of CSM were estimated as recommended in NRC (2011), as follows:

i) $A D C s$ of nutrients

$$
A D C=1-\frac{\mathrm{Cr}_{2} \mathrm{O}_{3} \text { infeed }}{\mathrm{Cr}_{2} \mathrm{O}_{3} \text { infeces }} \times \frac{\text { Nutrient contents infeces }}{\text { Nutrient contents infeed }}
$$

Table 1 - Ingredient and proximate composition of the reference and test diets and the Chlorella sorokiniana meal.

\begin{tabular}{|c|c|c|c|}
\hline Ingredients (\%) & $\begin{array}{c}\text { Reference } \\
\text { diet }\end{array}$ & $\begin{array}{c}70 \% \text { Ref }+30 \% \\
\text { Chlorella meal }\end{array}$ & $\begin{array}{c}\text { Chlorella } \\
\text { meal }\end{array}$ \\
\hline Soybean meal & 47.35 & - & - \\
\hline Corn & 28.31 & - & - \\
\hline Corn gluten meal & 11.20 & - & - \\
\hline Wheat bran & 10.00 & - & - \\
\hline Soybean oil & 1.71 & - & - \\
\hline Cellulose & 0.24 & - & - \\
\hline Methionine & 0.27 & - & - \\
\hline Chromium oxide III & 0.20 & - & - \\
\hline Vitamin and mineral mix ${ }^{1}$ & 0.80 & - & - \\
\hline $\mathrm{BHT}^{2}$ & 0.02 & - & - \\
\hline $\mathrm{NaCl}$ & 0.10 & - & - \\
\hline \multicolumn{4}{|l|}{ Proximate composition $(\%)^{3}$} \\
\hline Crude protein & 36.50 & 41.60 & 69.10 \\
\hline Lipids & 3.10 & 3.60 & 0.60 \\
\hline Crude fiber & 4.10 & 4.01 & 0.23 \\
\hline Ash & 4.84 & 5.38 & 8.70 \\
\hline Non-protein nitrogen & 0.39 & 0.41 & 0.77 \\
\hline Chromium oxide III & 0.160 & 0.160 & - \\
\hline Energy (kJ g-1) & 19.70 & 20.60 & 22.00 \\
\hline Essential amino acids $(\%)^{4}$ & 36.40 & 39.90 & 60.92 \\
\hline Arginine & 2.40 & 2.65 & 3.71 \\
\hline Threonine & 1.35 & 1.54 & 2.91 \\
\hline Valine & 1.56 & 1.89 & 3.60 \\
\hline Methionine & 0.76 & 0.81 & 1.08 \\
\hline Cystine & 0.65 & 0.72 & 1.07 \\
\hline Isoleucine & 1.47 & 1.67 & 2.73 \\
\hline Leucine & 3.38 & 3.88 & 5.69 \\
\hline Phenylalanine & 1.90 & 2.11 & 3.40 \\
\hline Lysine & 1.67 & 2.14 & 5.17 \\
\hline
\end{tabular}

${ }^{1}$ Premix (Nutrifish Guabiं; Campinas, SP, Brazil), warranty levels: Fe 1,500 mg; Cu 1,500 mg; Zn 12,500 mg; I 375 mg; Mn 12,500 mg; Se 87.5 mg; Co 125 mg; vit. A 2,500,000 IU; vit. D 3,600,000; vit. E 37,500 IU; vit. K 3,750 mg; vit.C 50,000 mg; vit. B1 4,000 mg; vit. B2 4,000 mg; vit. B6 4,000 $\mathrm{mg}$; vit. B12 4,000 mg; pantothenic acid 12,000 mg; biotin $15 \mathrm{mg}$; folic acid 1,250 mg; niacin 22,500 mg; BHT 15,000 mg; ${ }^{2}$ butylhydroxytoluene; ${ }^{3}$ as determined by analysis of raw material; ${ }^{4}$ except tryptophan.

ii) $A D C$ s of ingredients

$$
A D C_{T I}=A D C_{T D}+\left[\left(A D C_{T D}-A D C_{R D}\right) \times\left(\frac{0.7 \times N_{R D}}{0.3 \times N_{I}}\right)\right]
$$

where: $A D C=$ apparent digestibility coefficient; $T I=$ test ingredient; $T D=$ test diet; $R D=$ reference diet; $N$ $=$ quantity or percentage of ingredients or nutrients in the diet; $I=$ ingredient.

\section{Pricing model for the use of CSM as ingredient}

The model of price estimation for the use of CSM as dietary protein source was benchmarked against the main protein feedstuffs of the aquafeed industry, soybean meal (SBM) and fish meal (FM). From information derived from the World Bank database on historic prices of commodities (http://www.worldbank.org/en/ research/commodity-markets), the price of digestive 
protein contents of these feedstuffs were estimated as follows:

$D_{i}=(100 \times C) /\left(C P \times A D C_{(p)}\right) \quad$ Equation 1

where: $D_{i}=$ average price of digestive protein of feedstuffs; $C=$ average price of feedstuff (USD kg-1); $C P=$ crude protein contents of feedstuff $(\%) ; A D C_{(p)}=$ apparent digestibility coefficient of feedstuff protein.

Values of $A D C_{(p)}$ and $C P$ of FM and SBM were obtained from Gonçalves et al. (2009); values of C were estimated from the World Bank database on historic prices of commodities considering the average price of feedstuffs for the last five years. Price of CSM (UDS kg-1) was estimated from these data as follows:

$D_{(\text {chl })}=D_{i} \times\left(C P_{(\text {chl })} \times A D C_{(c h l)}\right) /\left(C P_{i} \times A D C_{i}\right)$ Equation 2

where: $D_{i}=$ price of digestive protein of feedstuffs; $D_{|c h l|}$ $=$ price of digestive protein of CSM; $C P_{i}=$ crude protein contents of feedstuff $(\%) ; C P_{(c h l)}=$ crude protein contents of CSM; $A D C_{(c h l)}=$ apparent digestibility coefficient of the protein of $\mathrm{CSM}_{;} A D C_{(i)}=$ apparent digestibility coefficient of the protein of feedstuff.

\section{Results and Discussion}

\section{Amino acid and macronutrients digestibility of Chlorella sorokiniana meal}

The composition and digestibility of protein, energy and amino acids found for CSM were similar to those of FM and SBM (Table 2). Except for histidine and methionine, essential amino acids contents of CSM were higher than contents of FM and SBM. Although the methionine content is comparatively lower than that of FM, the methionine digestibility of CSM was higher, which contributes with a greater amount of this amino acid in feed formulations. The nutritional methionine requirement of tilapia is $0.7 \%$ of the dietary protein. However, methionine is precursor of cystine, thus, it is recommended supplying $0.9 \%$ methionine to tilapia diets, and CSM meal can then be a good methionine source of diets as it may supply up to $1.02 \%$ digestible methionine (Diogenes et al., 2016; Michelato et al., 2013; Shiau, 2002).

Protein contents of microalgae are ordinarily determined by Kjeldahl method, which uses the 6.25 factor to convert total nitrogen $(\mathrm{N})$ into protein, an arguable procedure. When non-protein $\mathrm{N}$ present in chlorophyll, nucleic acids, free amino acids and amino saccharides molecules of microalgae are converted into crude protein with the use of the Kjeldahl method conversion factor, considerable biases can occur. However, the definition of a more realistic conversion factor for microalgae depends on the species, production system, growth stage of algae crop, harvesting and processing methods.

The suggested conversion factors for Chlorella sp. range between 5.02 for those harvested in the log phase of growth (highest protein concentration) and 4.84 for those harvested in the phase of logarithmic growth decline - death phase (higher concentration of lipids) (Templeton and Laurens, 2015; Angell et al., 2016). When using the conversion factor of 5.00, suggested by Angell et al. (2016), CP contents of the CSM drop from $69 \%$ to $55 \%$, dry matter basis, yet a high protein content level. However, given that establishing a correlation between the CP levels of feed with protein levels of feces samples is rather challenging, values determined by the Kjeldahl method were herein conserved and used.

Lysine is the most limiting amino acid in fish diets, especially when plant protein sources are used as FM surrogates. Dietary lysine considerably affects growth performance, health and retention of $\mathrm{N}$ by fish (Li et al., 2009; Diogenes et al., 2016; NRC, 2011; Shiau, 2002). Lysine contents of CSM are considerably high $-5.17 \%$ of

Table 2 - Comparison of CSM, fishmeal and soybean meal in terms of nutritional composition, apparent digestibility coefficient and digestible nutrients for tilapia.

\begin{tabular}{|c|c|c|c|c|c|c|}
\hline \multirow{2}{*}{ Nutrient (\%) } & \multicolumn{2}{|c|}{ Chlorella meal ${ }^{1}$} & \multicolumn{2}{|c|}{ Fishmeal $^{2}$} & \multicolumn{2}{|c|}{ Soybean meal ${ }^{2}$} \\
\hline & Composition $^{3}$ & ADC & Composition $^{3}$ & ADC & Composition $^{3}$ & $\mathrm{ADC}$ \\
\hline Protein & 69.06 & $90.51 \pm 0.89(62.50)$ & 60.15 & 82.59 (49.68) & 51.70 & $94.13(48.67)$ \\
\hline Energy $\left(\mathrm{kJ} \mathrm{g}^{-1}\right)$ & 22.70 & $84.22 \pm 4.78(19.10)$ & 17.90 & 95.29 (17.10) & 20.30 & 84.12 (17.10) \\
\hline Dry matter & - & $82.71 \pm 5.28(78.83)$ & - & 82.60 (74.79) & 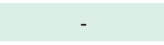 & $85.30(74.82)$ \\
\hline \multicolumn{7}{|c|}{ Essential amino acids ${ }^{4}$} \\
\hline Arginine & 3.71 & $96.10 \pm 0.79(3.57)$ & 3.64 & $89.39(3.26)$ & 3.55 & $94.53(3.35)$ \\
\hline Phenylalanine & 3.41 & $91.78 \pm 1.08(3.13)$ & 2.68 & $88.89(2.39)$ & 2.83 & $97.58(2.76)$ \\
\hline Histidine & 1.03 & $93.85 \pm 1.69(0.96)$ & 1.28 & $92.24(1.18)$ & 1.43 & $94.40(1.35)$ \\
\hline Isoleucine & 2.74 & $93.29 \pm 0.96(2.55)$ & 2.57 & $89.70(2.31)$ & 2.63 & $92.64(2.44)$ \\
\hline Leucine & 5.70 & $90.69 \pm 1.28(5.17)$ & 4.47 & 92.59 (4.14) & 4.44 & $93.32(4.14)$ \\
\hline Lysine & 5.17 & $90.35 \pm 0.81(4.67)$ & 4.51 & $93.63(4.22)$ & 3.06 & $97.01(2.96)$ \\
\hline Methionine & 1.08 & $94.40 \pm 0.60(1.02)$ & 1.73 & $87.26(1.51)$ & 0.49 & $90.70(0.44)$ \\
\hline Threonine & 2.92 & $91.82 \pm 1.13(2.68)$ & 2.47 & $83.93(2.08)$ & 2.02 & $90.40(1.82)$ \\
\hline Valine & 3.61 & $91.65 \pm 0.99(3.31)$ & 2.78 & $92.46(2.57)$ & 2.62 & $90.00(2.36)$ \\
\hline
\end{tabular}

TValues determined by analysis \pm standard error; ${ }^{2}$ Reference: Gonçalves et al. (2009); ${ }^{3}$ Dry matter basis; ${ }^{4}$ Except tryptophan; ADC = apparent digestibility coefficient. Values within brackets represent $\%$ of digestible nutrient, CSM = Chlorella sorokiniana meal. 
the protein content - and dietary requirements of tilapia are $1.6 \%$ of the dietary protein (Shiau, 2002). Therefore, CSM can also be used as dietary lysine source, reducing, or even sparing the inclusion of synthetic lysine in tilapia diets. In addition to reducing costs, this characteristic can improve the efficiency of diets, since synthetic amino acids are more easily leached and their addition to diets can influence the balance of amino acids, not to mention that tilapia does not seem to use synthetic amino acids efficiently (Zarate et al., 1999; Liebert, 2009; Liebert and Benkendorff, 2007).

When comparing original data on CSM of this study with FM and SBM data from the reference literature (e.g. Gonçalves et al., 2009), it is important to consider the array of variables that possibly influence the results of both digestibility trials especially type and processing method of the reference diets (Table 3). Gonçalves et al. (2009) used semi-purified diets formulated from gelatin, casein and dextrin plus a lipid source to prevent possible interactions between ingredients and avoid the presence of antinutritional factors. However, the use of semi-purified diets, which are not usually as palatable as practical diets, may decrease feed intake, a source of disturbance in digestibility trials results, since animals may not ingest the proper amount of feed eliciting normal functions of the digestive system (NRC, 2011).

The extrusion process of diets causes denaturation of some proteins and gelatinization of the starch thus yielding better use of nutrients and, consequently, higher values of digestibility comparatively to pelleted diets (Ma et al., 2016). Comparing digestibility values recorded by Gonçalves et al. (2009), who used pelleted diets, and results herein reported from the use of extruded diets, recorded ADCs in both studies do not vary, that is, the processing method had less influence than dietary ingredients did on diet digestibility, or no influence at all. This observation corroborates Sklan et al. (2004) who studied the digestibility of different feedstuffs (fishmeal included) in extruded and pelleted feeds for tilapia and reported no significant differences in the ADCs of protein and lipids.

Table 3 - Comparison of the experimental procedures used in the current work with the reference literature.

\begin{tabular}{lcc}
\hline & Original research data & Gonçalves et al. (2009) \\
\hline Tilapia juvenile initial & $78.01 \pm 1.87$ & $82.00 \pm 5.00$ \\
weight (g) & Indirect/passive & Indirect/passive \\
Feces collection method & $\mathrm{Cr}_{2} \mathrm{O}_{3}$ & $\mathrm{Cr}_{2} \mathrm{O}_{3}$ \\
Marker & 0.20 & 0.10 \\
Marker quantity (\%) & Extruded & Pelleted \\
Feed processing & Practical & Semi-purified \\
Diet & 36.50 \\
\hline Proximate composition of control diets in dry matter (\%) \\
\hline Crude protein & 20.40 & 36.05 \\
Energy (kJ g-1) & 4.10 & 17.60 \\
Fiber & 3.10 & 5.24 \\
Lipids & \multicolumn{3}{l}{4.72} \\
\hline
\end{tabular}

As a matter of fact, Koprucu and Ozdemir (2005) reported ADCs of protein of $90 \%$ and $87 \%$ for anchovy meal $(71 \% \mathrm{CP})$ and soybean meal $(53 \% \mathrm{CP})$, respectively, for juvenile Nile tilapia $(15 \pm 0.1 \mathrm{~g})$. Sklan et al. (2004) has also reported ADCs of dietary protein of $90 \%$ and $96 \%$ for FM (63\% CP) and SBM (44\% CP), respectively, when working with hybrid tilapia (O. niloticus $\times$ O. aureus) with $150 \mathrm{~g}$ of initial body weight.

The protein contents of fish meal may vary from $59-72 \%$ (NRC, 2011) depending on fish species, processing methods and storage conditions. Considering the composition of the fish meal (60\% CP) used by Gonçalves et al. (2009), it is safe to say that the authors have used a low-quality protein source in their assays, as some fish meal can contain $72 \% \mathrm{CP}$. However, the pricing model proposed in the present study can be used for different comparisons and data reported by Gonçalves et al. (2009) were chosen for comparison purposes because of the similarity of the experimental conditions, especially tilapia strain and initial body weight.

\section{Estimation of price range for the use CSM as dietary protein source}

Prices of FM have detached from that of SBM in recent years. Therefore, average price estimations were considered for the last five years. A steady plateau of prices at $1.68 \mathrm{USD} \mathrm{kg}^{-1}$ and $0.40 \mathrm{USD} \mathrm{kg}^{-1}$ for FM and SBM, respectively, was identified (Figure 1). From the calculation below, the price of digestible protein of FM and SBM were estimated at $3.38 \mathrm{USD} \mathrm{kg}^{-1}$ and $0.82 \mathrm{USD} \mathrm{kg}^{-1}$, respectively.

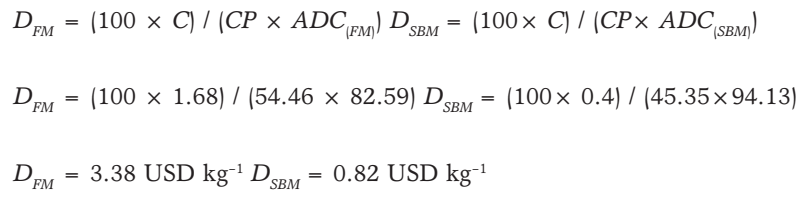

where: $D_{S B M}=$ price of SBM digestible protein; $D_{F M}=$ price of FM digestible protein; $C=$ average ingrediente price; $C P=$ ingrediente crude protein; $A D C=$ apparent digestibility coefficient.

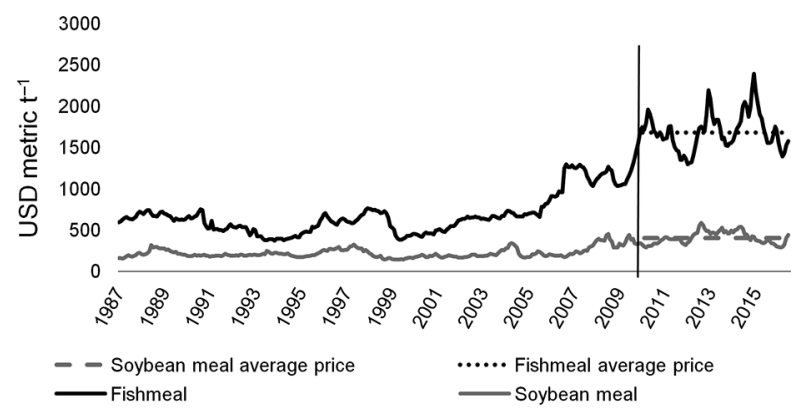

Figure 1 - Price history of fish meal (FM) and soybean meal (SBM) from 1987 to June 2016 and average price of the last 5 years of these ingredients. Source: World Bank database on historic of prices of commodities (http://www.worldbank.org/en/research/ commodity-markets). 
It is thus estimated that CSM can replace FM and SBM as dietary protein source when digestible protein contents are priced at a maximum of USD $4.25 \mathrm{~kg}^{-1}$ or USD $1.06 \mathrm{~kg}^{-1}$, respectively (Equation 2). When the value of the whole product is considered, CSM should be priced at a maximum of $2.65 \mathrm{USD} \mathrm{kg}^{-1}$ and 0.66 USD kg-1 to elicit replacement of FM and SBM, respectively. These estimates are based upon the unconfirmed hypothesis that CSM can replace both ingredients without hampering growth performance of fish.

Although no reports on the replacement of FM by Chlorella sp. were found, other microalgae species such as Isochrysis sp. (Tibaldi et al., 2015); Nanofrustulum sp. and Tetraselmis sp. (Kiron et al., 2012); Navicula sp. and Nannochloropsis salina (Patterson and Gatlin, 2013), and Spirulina sp. (Palmegiano et al., 2005) have already been evaluated. The highest level of substitution tested was $60 \%$ (Palmegiano et al., 2005), and growth performance of fish were not hampered at any dietary level.

Although ADC of CSM by tilapia herein registered was $91 \%$, values recorded for the digestibility of Chlorella meal by other animals ranged from 68 to $80 \%$ (Becker, 2007; Kotrbacek et al., 2015). However, tilapia is an herbivorous fish that may behave as an omnivore when adult. The ADC of CSM for many other farmed, neotropical species, such as the omnivore pacu, Piaractus mesopotamicus, or the carnivore dourado, Salminus brasiliensis, are probably lower than those recorded for tilapia. In this case, using CSM in the feed and nutrition of these species is feasible only when the price of digestible protein of CSM does not exceed 4.25 USD $\mathrm{kg}^{-1}$.

Future evaluations of CSM as alternative protein source to FM in tilapia nutrition should take into account that adding FM to tilapia feed formulations is rather low - ordinarily circa 2 - $5 \%$ (Chiu et al., 2013). As a matter of fact, the use of FM in tilapia diets is possibly unnecessary (Koch et al., 2016). Consequently, it is logical to use CSM as replacement to SBM as protein source, or as it is a good source of digestible lysine, CSM could replace costly synthetic lysine sources.

Pricing of microalgae as source of eicosapentaenoic (EPA) and docosahexaenoic (DHA) fatty acids in replacement to fish oil in aquafeeds was studied by Chauton et al. (2015), who reported that it is feasible to use microalgae meal in aquafeeds when priced at 2.4 USD kg-1 or $8.0 \mathrm{USD} \mathrm{kg}^{-1}$ of the equivalent amount in EPA and DHA, respectively. Considering the contribution in protein, energy and amino acids in formulations, and using the hedonic model of price prediction, Maisashvili et al. (2015) reported that the use of Chlorella pyrenoidosa meal in aquafeeds is feasible when priced at a maximum of $0.64 \mathrm{USD} \mathrm{kg}^{-1}$ for the period studied (2005-2012). The results of these studies to a certain extent corroborate those reported here, since the estimated prices or values ranged between the main, traditional protein sources of aquafeeds - FM and SBM.
The price range between USD $4.25 \mathrm{~kg}^{-1}$ and USD $1.06 \mathrm{~kg}^{-1}$ estimated in this study still requires validation in growth performance studies and assessment of complete FM replacement. However, these values can already be used as suggestive and benchmarking in the market price formation for the use of CSM in tilapia nutrition.

\section{References}

Angell, A.R.; Mata, L.; Nys, R.; Paul, N.A. 2016. The protein content of seaweeds: a universal nitrogen-to-protein conversion factor of five. Journal of Applied Phycology 28: 511-524.

Association of Official Analitycal Chemists [AOAC]. 1999. Official Methods of Analysis. 17ed. AOAC, Gaithersburg, MD, USA.

Becker, E.W. 2007. Micro-algae as a source of protein. Biotechnology Advances 25: 207-210.

Chauton, M.S.; Reitan, K.I.; Norsker, N.H.; Tveteras, R.; Kleivdal, H.T. 2015. A techno-economic analysis of industrial production of marine microalgae as a source of EPA and DHA-rich raw material for aquafeed: research challenges and possibilities. Aquaculture 436: 95-103.

Chisti, Y. 2007. Biodiesel from microalgae. Biotechnology Advances 25: 294-306.

Chisti, Y. 2008. Biodiesel from microalgae beats bioethanol. Trends in Biotechnology 26: 126-131.

Chiu, A.; Li, L.P.; Guo, S.J.; Bai, J.F.; Fedor, C.; Naylor, R.L. 2013. Feed and fishmeal use in the production of carp and tilapia in China. Aquaculture 414: 127-134.

Christaki, E.; Florou-Paneri, P.; Bonos, E. 2011. Microalgae: a novel ingredient in nutrition. International Journal of Food Sciences and Nutrition 62: 794-799.

Demirbas, A.; Demirbas, M.F. 2011. Importance of algae oil as a source of biodiesel. Energy Conversion and Management 52: 163-170.

Diogenes, A.F.; Fernandes, J.B.K.; Dorigam, J.C.P.; Sakomura, N.K.; Rodrigues, F.H.F.; Lima, B.T.M.; Gonçalves, F.H. 2016. Establishing the optimal essential amino acid ratios in juveniles of Nile tilapia (Oreochromis niloticus) by the deletion method. Aquaculture Nutrition 22: 435-443.

Eknath, A.E.; Hulata, G. 2009. Use and exchange of genetic resources of Nile tilapia (Oreochromis niloticus). Reviews in Aquaculture 1: 197-213.

Gonçalves, G.S.; Pezzato, L.E.; Barros, M.M.; Rocha, D.F.; Kleeman, G.K.; Santa Rosa, M.J. 2009. Digestible nutrients of Nile tilapia feed. Boletim do Instituto de Pesca 35: 201-213 (in Portuguese, with abstract in English).

Gouveia, L.; Choubert, G.; Gomes, E.; Rema, P.; Empis, J. 1998. Use of Chlorella vulgaris as a carotenoid source for rainbow trout: effect of dietary lipid content on pigmentation, digestibility and retention in the muscle tissue. Aquaculture International 6: 269-279.

Gouveia, L.; Choubert, G.; Pereira, N.; Santinha, J.; Empis, J.; Gomes, E. 2002. Pigmentation of gilthead seabream, Sparus aurata (L. 1875), using Chlorella vulgaris (Chlorophyta, Volvocales) microalga. Aquaculture Research 33: 987-993.

Gouveia, L.; Rema, P.; Pereira, O.; Empis, J. 2003. Colouring ornamental fish (Cyprinus carpio and Carassius auratus) with microalgal biomass. Aquaculture Nutrition 9: 123-129. 
Grammes, F.; Reveco, F.E.; Romarheim, O.H.; Landsverk, T.; Mydland, L.T.; Overland, M. 2013. Candida utilis and Chlorella vulgaris counteract intestinal inflammation in Atlantic salmon (Salmo salar L.). PLoS ONE 8: e83213.

Kiron, V.; Phromkunthong, W.; Huntley, M.; Archibald, I.; Scheemaker, G. 2012. Marine microalgae from biorefinery as a potential feed protein source for Atlantic salmon, common carp and whiteleg shrimp. Aquaculture Nutrition 18: 521-531.

Koch, J.F.; Rawles, S.D.; Webster, C.D.; Cummins, V.; Kobayashi, Y.; Thompson, K.R.; Gannam, A.L.; Twibell, R.G.; Hyde, N.M. 2016. Optimizing fish meal-free commercial diets for Nile tilapia, Oreochromisniloticus. Aquaculture 452: 357-366.

Koprucu, K.; Ozdemir, Y. 2005. Apparent digestibility of selected feed ingredients for Nile tilapia (Oreochromis niloticus). Aquaculture 250: 308-316.

Kotrbacek, V.; Doubek, J.; Doucha, J. 2015. The chlorococcalean alga Chlorella in animal nutrition: a review. Journal of Applied Phycology 27: 2173-2180.

Krogdahl, A.; Gajardo, K.; Kortner, T.M.; Penn, M.; Gu, M.; Berge, G.M.; Bakke, A.M. 2015. Soya saponins induce enteritis in Atlantic salmon (Salmo salar L.). Journal of Agricultural and Food Chemistry 63: 3887-3902.

Krogdahl, A.; Penn, M.; Thorsen, J.; Refstie, S.; Bakke, A.M. 2010. Important antinutrients in plant feedstuffs for aquaculture: an update on recent findings regarding responses in salmonids. Aquaculture Research 41: 333-344.

Li, P.; Mai, K.S.; Trushenski, J.; Wu, G.Y. 2009. New developments in fish amino acid nutrition: towards functional and environmentally oriented aquafeeds. Amino Acids 37: 43-53.

Liebert, F. 2009. Current knowledge of protein and amino acid nutrition and metabolism in fish. Journal of Animal Physiology and Animal Nutrition 93: 787-793.

Liebert, F.; Benkendorff, K. 2007. Modeling lysine requirements of Oreochromis niloticus due to principles of the diet dilution technique. Aquaculture 267: 100-110.

Ma, F.; Li, X.Q.; Li, B.A.; Leng, X.J. 2016. Effects of extruded and pelleted diets with differing lipid levels on growth, nutrient retention and serum biochemical indices of tilapia (Oreochromis aureus $\times$ Tilapia nilotica). Aquaculture Nutrition 22: 61-71.

Mahboob, S.; Rauf, A.; Ashraf, M.; Sultana, T.; Sultana, S.; Jabeen, F.; Rajoka, M.I.; Al-Balawi, H.F.A.; Al-Ghanim, K.A. 2012. High-density growth and crude protein productivity of a thermotolerant Chlorella vulgaris: production kinetics and thermodynamics. Aquaculture International 20: 455-466.

Maisashvili, A.; Bryant, H.; Richardson, J.; Anderson, D.; Wickersham, T.; Drewery, M. 2015. The values of whole algae and lipid extracted algae meal for aquaculture. Algal Research 9: 133-142.

Michelato, M.; Furuya, W.M.; Graciano, T.S.; Vidal, L.V.O.; Xavier, T.O.; Moura, L.B.; Furuya, V.R.B. 2013. Digestible methionine plus cystine requirement for Nile tilapia from 550 to 700 g. Revista Brasileira de Zootecnia 42: 7-12.

Nascimento, I.A.; Marques, S.S.I.; Cabanelas. I.T.D.; Carvalho, G.C.; Nascimento, M.A.; Souza, C.O.; Druzian, J.I.; Hussain, J.; Liao, W. 2014. Microalgae versus land crops as feedstock for biodiesel: productivity, quality, and standard compliance. Bioenergy Research 7: 1002-1013.
National Research Council [NRC]. 2011. Nutrient Requirement of Fish And Shrimp. National Academies Press, Washington, DC, USA.

Ng, W.-K.; Romano, N. 2013. A review of the nutrition and feeding management of farmed tilapia throughout the culture cycle. Reviews in Aquaculture 5: 220-254.

Palmegiano, G.B.; Agradi, E.; Forneris, G.; Gai, F.; Gasco, L.; Rigamonti, E.; Sicuro, B.; Zoccarato, I. 2005. Spirulina as a nutrient source in diets for growing sturgeon (Acipenser baeri). Aquaculture Research 36: 188-195.

Patterson, D.; Gatlin, D.M. 2013. Evaluation of whole and lipidextracted algae meals in the diets of juvenile red drum (Sciaenops ocellatus). Aquaculture 416: 92-98.

Radhakrishnan, S.; Saravana Bhavan, P.; Seenivasan, C.; Shanthi, R.; Muralisankar, T. 2014. Replacement of fishmeal with Spirulina platensis, Chlorella vulgaris and Azolla pinnata on nonenzymatic and enzymatic antioxidant activities of Macrobrachium rosenbergii. The Journal of Basic and Applied Zoology 67: 25-33.

Ranjitha, J.; Vijayalakshmi, S. 2015. Micro-algae as a substrate for biofuel production: a review. Research Journal of Biotechnology 10: 99-107.

Roy, S.S.; Pal, R. 2015. Microalgae in aquaculture: a review with special references to nutritional value and fish dietetics. Proceedings of the Zoological Society 68: 1-8.

Sarker, P.K.; Gamble, M.M.; Kelson, S.; Kapuscinski, A.R. 2016a. Nile tilapia (Oreochromis niloticus) show high digestibility of lipid and fatty acids from marine Schizochytrium sp. and of protein and essential amino acids from freshwater Spirulina sp. feed ingredients. Aquaculture Nutrition 22: 109-119.

Sarker, P.K.; Kapuscinski, A.R.; Lanois, A.J.; Livesey, E.D.; Bernhard, K.P.; Coley, M.L. 2016b. Towards sustainable aquafeeds: complete substitution of fish oil with marine microalga Schizochytrium sp. improves growth and fatty acid deposition in juvenile Nile tilapia (Oreochromis niloticus). PLoS ONE 11: e0156684.

Sergejevova, M.; Masojidek, J. 2012. Chlorella biomass as feed supplement for freshwater fish: sterlet, Acipenser ruthenus. Aquaculture Research 44: 157-159.

Shiau, S.-Y. 2002. Tilapia, Oreochromis spp. p. 273-292. In: Webster, C.D.; Lim, C.E., eds. Nutrients Requirements and Feeding of Finfish for Aquaculture. CABI International, Cambridge, MA, USA.

Singh, A.K.; Singh, M.P. 2014. Importance of algae as a potential source of biofuel. Cellular and Molecular Biology 60: 106-109.

Sklan, D.; Prag, T.; Lupatsch, I. 2004. Apparent digestibility coefficients of feed ingredients and their prediction in diets for tilapia Oreochromis niloticus $\times$ Oreochromis aureus (Teleostei, Cichlidae). Aquaculture Research 35: 358-364.

Templeton, D.W.; Laurens, L.M.L. 2015. Nitrogen-to-protein conversion factors revisited for applications of microalgal biomass conversion to food, feed and fuel. Algal Research 11: 359-367.

Tibaldi, E.; Chini Zittelli, G.; Parisi, G.; Bruno, M.; Giorgi, G.; Tulli, F.; Venturini, S.; Tredici, M.R.; Poli, B.M. 2015. Growth performance and quality traits of European sea bass (D. labrax) fed diets including increasing levels of freeze-dried Isochrysis sp. (T-ISO) biomass as a source of protein and n-3 long chain PUFA in partial substitution of fish derivatives. Aquaculture 440: 60-68. 
Tulli, F.; Zittelli, G.C.; Giorgi, G.; Poli, B.M.; Tibaldi, E.; Tredici, M.R. 2012. Effect of the inclusion of dried Tetraselmis suecica on growth, feed utilization, and fillet composition of European sea bass juveniles fed organic diets. Journal of Aquatic Food Product Technology 21: 188-197.

Xu, W.; Gao, Z.; Qi, Z.; Qiu, M.; Peng, J.-q.; Shao, R. 2014. Effect of dietary Chlorella on the growth performance and physiological parameters of Gibel carp, Carassius auratus gibelio. Turkish Journal of Fisheries and Aquatic Sciences 14: 53-57.
Zahran, E.; Risha, E. 2014. Modulatory role of dietary Chlorella vulgaris powder against arsenic-induced immunotoxicity and oxidative stress in Nile tilapia (Oreochromis niloticus). Fish and Shellfish Immunology 41: 654-662.

Zarate, D.D.; Lovell, R.T.; Payne, M. 1999. Effects of feeding frequency and rate of stomach evacuation on utilization of dietary free and protein-bound lysine for growth by channel catfish Ictalurus punctatus. Aquaculture Nutrition 5: 17-22. 